\title{
EFIKASI HERBISIDA PARAKUAT DIKLORIDA TERHADAP GULMA UMUM PADA TANAMAN UBI KAYU (Manihot esculenta Crantz.)
}

\author{
Dini Ari Murti, Nanik Sriyani \& Setyo Dwi Utomo \\ Jurusan Agroteknologi, Fakultas Pertanian, Universitas Lampung \\ Jalan Prof. Soemantri Brojonegoro, No.1 Bandar Lampung 35145 \\ E-mail : nsriyani06@yahoo.co.id.
}

\begin{abstract}
ABSTRAK
Tanaman ubi kayu (Manihot esculenta Crantz.) merupakan tanaman pangan yang hasilnya dapat diolah menjadi bahan makanan pokok. Pemeliharaan menjadi hal yang penting untuk menjaga kualitas tanaman agar lebih baik. Gulma merupakan salah satu faktor yang dapat menurunkan kualitas dan kuantitas produksi akibat adanya kompetisi dalam penyerapan hara, air, cahaya dan ruang tumbuh. Penelitian ini bertujuan untuk mengetahui efikasi herbisida berbahan aktif parakuat diklorida dan dosis parakuat diklorida yang tepat dalam mengendalikan gulma pada tanaman ubi kayu. Penelitian dilakukan di Kebun Percobaan Natar, Lampung Selatan dan Laboratorium Ilmu Gulma Universitas Lampung. Penelitian dilakukan dalam Rancangan Acak Kelompok (RAK) dengan 7 perlakuan dan 4 ulangan. Perlakuan yang diterapkan dalam penelitian ini meliputi dosis 414 $\mathrm{g} / \mathrm{ha}, 552 \mathrm{~g} / \mathrm{ha}, 690 \mathrm{~g} / \mathrm{ha}, 828 \mathrm{~g} / \mathrm{ha}, 966 \mathrm{~g} / \mathrm{ha}$, penyiangan mekanis dan kontrol (tanpa pengendalian gulma). Data yang diperoleh diuji Bartlett untuk homogenitas ragam dan Uji Tukey untuk menguji additivitas. Bila homogen, data dianalisis ragam. Bila uji $\mathrm{F}$ analisis ragam nyata, dilanjutkan dengan uji BNT 5\% untuk pemisahan nilai tengah. Hasil penelitian menunjukkan bahwa bahwa herbisida parakuat diklorida dengan dosis $414 \mathrm{~g} / \mathrm{ha}-966 \mathrm{~g} / \mathrm{ha}$ mampu menekan pertumbuhan gulma total ubi kayu sampai 8 minggu setelah aplikasi (MSA) serta mampu mengendalikan gulma golongan daun lebar Ipomoea triloba dan Richardia brasiliensis hingga 8 MSA serta gulma golongan rumput Digitaria ciliaris hingga 4 MSA namun demikian parakuat diklorida dosis $414 \mathrm{~g} / \mathrm{ha}-966 \mathrm{~g} / \mathrm{ha} \mathrm{tidak}$ dapat mengendalikan gulma golongan rumput Echinochloa colonum dari 2 MSA hingga 8 MSA.
\end{abstract}

Kata kunci: Digitaria ciliaris, Echinochloa colonum, efikasi, Ipomoea triloba, parakuat diklorida, Richardia brasiliensis, ubi kayu

\section{PENDAHULUAN}

Tanaman pangan merupakan bahan makanan tinggi karbohidrat yang dikonsumsi oleh sebagian besar penduduk dunia dalam kurun waktu yang panjang. Salah satu tanaman pangan yang mengandung karbohidrat tinggi adalah ubi kayu (Manihot esculenta Crantz.). Seiring dengan perkembangan teknologi dan zaman kebutuhan pangan sangat sulit dipenuhi karena makin berkurangnya areal lahan. Di Indonesia, luas panen ubi kayu pada tahun 2011 adalah 1.184.696 ha, sedangkan pada tahun 2013 menurun menjadi 1.065.752 ha (Badan Pusat Statistik, 2013). Dalam teknik budidaya salah satu faktor yang mempengaruhi produksi tanaman ubi kayu adalah pemeliharaan tanaman dan pengendalian gulma. Gulma didefinisikan sebagai tumbuhan yang tidak dikehendaki dan memiliki pengaruh negatif,sehingga kehadirannya tidak dikehendaki manusia (Yuni dan Suryani, 2008). Meskipun gulma tidak mengakibatkan kematian pada tanaman ubi kayu tetapi akan menimbulkan hasil yang kurang memuaskan karena terjadi persaingan pengambilan zat hara, cahaya matahari dan ruang tumbuh yang terbatas (Sembodo, 2010). Kehadiran gulma pada tanaman pangan dapat menimbulkan kerugian karena terjadinya kompetisi. Penurunan hasil dapat mencapai $50 \%$ bila pengelolaan gulma kurang mendapat perhatian (Anwar, 2002). Oleh karena itu keberadaan gulma perlu ditekan agar tidak mengganggu tanaman pokok. Salah satu upaya yang dilakukan dalam pengendalian gulma pada tanaman ubi kayu adalah dengan menggunakan herbisida (Sembodo, 2010). Parakuat diklorida merupakan salah satu herbisida kontak bersperktrum luas yang pada umumnya diaplikasikan secara pasca tumbuh pada lahan ubi kayu saat umur tanaman 3 bulan. Menurut Muktamar (2004), parakuat merupakan herbisida kontak dan bila molekul herbisida ini terkena sinar matahari setelah berpenetrasi ke dalam daun atau bagian lain yang hijau maka molekul ini akan bereaksi menghasilkan molekul hidrogen peroksida. Parakuat diklorida bekerja dalam sistem 
membran fotosintesis yang disebut Fotosistem I, yang menghasilkan elektron bebas untuk menjalankan proses fotosintesis (Sriyani dan Salam, 2008; Sarbino dan Syahputra, 2012). Herbisida parakuat diklorida mampu memperbaiki sifat kimia tanah, meningkatkan persentase pengendalian gulma, menurunkan bobot kering gulma dan meningkatkan komponen hasil tanaman ubi kayu (Adnan, dkk., 2012). Penelitian ini bertujuan untuk mengetahui efikasi herbisida berbahan aktif parakuat diklorida dan mengetahui dosis parakuat diklorida dalam mengendalikan gulma pada tanaman ubi kayu.

\section{BAHAN DAN METODE}

Penelitian ini dilakukan di kebun percobaan Universitas Lampung (Unila), Kecamatan Natar, Kabupaten Lampung Selatan dan Laboratorium Ilmu Gulma Universitas Lampung pada bulan November 2014 sampai dengan Maret 2015. Bahan-bahan yang digunakan pada penelitian ini adalah tanaman ubi kayu varietas UJ-3 (Thailand) (umur \pm 3 bulan), herbisida Gramoxone 276 SL (bahan aktif parakuat diklorida 276 $\mathrm{g} / \mathrm{l}$ ), cat, pupuk Urea, TSP, $\mathrm{KCl}$ dan air. Alat-alat yang digunakan dalam penelitian ini yaitu knapsack sprayer, nosel merah, gelas ukur $100 \mathrm{ml}$ dan $1.000 \mathrm{ml}$, plastik besar, meteran, spidol, ember, cangkul, kuadran, oven listrik, timbangan analitik, kamera, pipet, patok, dan alat tulis. Penelitian dilakukan menggunakan Rancangan Acak Kelompok (RAK) yang terdiri atas 7 perlakuan dan 4 ulangan, sehingga diperoleh 28 unit percobaan. Perlakuan yang diterapkan dalam penelitian ini meliputi dosis $414 \mathrm{~g} / \mathrm{ha}, 552 \mathrm{~g} / \mathrm{ha}, 690 \mathrm{~g} / \mathrm{ha}, 828 \mathrm{~g} / \mathrm{ha}, 966 \mathrm{~g} / \mathrm{ha}$, penyiangan mekanis dan kontrol (tanpa pengendalian gulma). Pada setiap plot percobaan diambil 8 tanaman contoh yang dipilih secara acak dan selanjutnya digunakan sebagai contoh tanaman pengamatan.

Data yang diperoleh diuji Bartlett untuk homogenitas ragam dan Uji Tukey untuk menguji additivitas. Bila homogen, data dianalisis ragam. Bila uji $\mathrm{F}$ analisis ragam nyata, dilanjutkan dengan uji BNT $5 \%$ untuk pemisahan nilai tengah. Tiap petak percobaan berukuran $6 \mathrm{mx} 10 \mathrm{~m}$. Setiap petak percobaan terdiri dari 60 tanaman ubi kayu dengan jarak antar tanaman 1 m x $1 \mathrm{~m}$. Lahan dibagi menjadi empat kelompok percobaan yang ditentukan sedemikian rupa sehingga gulma sasaran relatif merata pada setiap blok. Ubi kayu ditanam dalam petak percobaan menggunakan stek batang berukuran $25 \mathrm{~cm}$. Pemupukan dilakukan satu kali pada waktu tanam dengan dosis $20 \mathrm{~kg} \mathrm{~N}(43,478 \mathrm{~kg}$

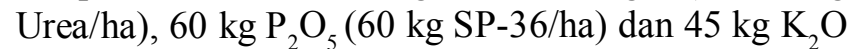
(75 kg KCl/ha). Pemupukan dilakukan dengan cara ditugal sedalam $5 \mathrm{~cm}$ dengan jarak $10 \mathrm{~cm}$ dari pangkal batang tanaman. Pemeliharaan dilakukan setiap minggu. Penyiangan mekanis dilakukan satu kali bersamaan dengan aplikasi herbisida. Aplikasi herbisida parakuat diklorida dilakukan satu kali saat tanaman ubi kayu berumur 3 bulan dengan cara menyemprotkan larutan herbisida yang telah dicampurkan dengan air pada gulma secara menyeluruh (blanket) dengan menggunakan knapsack sprayer bernosel merah dengan volume semprot sebesar 538 1/ha. Sebelum aplikasi herbisida dilakukan, tanaman yang berada dalam petak pengamatan dilindungi dengan plastik hitam. Gulma diambil dengan menggunakan kuadran berukuran 0,5 m $\mathrm{x} 0,5 \mathrm{~m}$ pada titik pengambilan sampel dengan masingmasing 2 titik pengambilan secara menyilang per petak percobaan. Pengambilan sampel gulma dilakukan sebanyak 3 kali yaitu pada 2, 4, dan 8 MSA. Gulma yang berada pada petak kuadrat dipotong tepat setinggi permukaan tanah. Gulma yang telah dipotong lalu dipilah menurut spesiesnya kemudian dipisahkan antara bagian gulma yang masih hidup/segar dengan yang telah mati/ berwarna cokelat. Gulma yang masih segar kemudian dikeringkan dengan menggunakan oven dengan suhu 80 ${ }^{\circ} \mathrm{C}$ selama 48 jam. Variabel pengamatan meliputi tanaman (tinggi tanaman) dan gulma (SDR gulma awal, bobot kering gulma total dan dominan, persentase penutupan gulma total dan persentase keracunan gulma total).

\section{HASIL DAN PEMBAHASAN}

Berdasarkan nilai SDR gulma yang diperoleh saat aplikasi telah menunjukkan bahwa pada saat aplikasi, terdapat 15 spesies gulma dominan dari golongan daun lebar, rumput dan teki pada petak percobaan. Spesies gulma dari golongan daun lebar berjumlah 11 spesies gulma, golongan rumput berjumlah 3 spesies gulma dan dari golongan teki hanya terdapat 1 spesies gulma. Hal ini menunjukkan bahwa lahan ini memiliki gulma dominan yang beragam. Urutan dominansi dari 16 spesies gulma yang ditemukan bila dilihat dari nilai SDR tertinggi hingga terendah yaitu Richardia brasiliensis (18\%), Cleome rutidosperma (15\%), Digitaria ciliaris (10\%), Lindernia cicciata (8\%), Cyperus rotundus (8\%), Ipomoea triloba (7\%), Echinochloa colonum (7\%), Eleusine indica (6\%), Asystasia gangetica (5\%), Borreria alata (5\%), Phyllanthus niruri (4\%), Croton hirtus (3\%), Mimosa invisa (3\%), Ludwigia hyssopifolia (2\%), dan Calopogonium mucunoides (1\%).

Pada penutupan gulma total, berdasarkan hasil pengamatan yang dilakukan secara visual yaitu pada 2 , 4, dan 8 MSA pada semua taraf dosis herbisida yang 
diuji, herbisida parakuat diklorida dapat menekan pertumbuhan gulma yang disajikan pada Tabel 1. Pada pengamatan 2, 4, dan 8 MSA dapat terlihat bahwa penutupan gulma total pada semua taraf dosis herbisida parakuat diklorida yang diuji tertekan. Gulma total pada semua perlakuan dosis herbisida parakuat diklorida yang diuji mampu menekan penutupan gulma total sama seperti pada petak penyiangan mekanis. Artinya bahwa pada pengamatan 2, 4 dan 8 MSA herbisida parakuat diklorida $414 \mathrm{~g} / \mathrm{ha}-966 \mathrm{~g} / \mathrm{ha}$ efektif menekan penutupan gulma total.

Pada bobot kering gulma total, hasil penelitian menunjukkan bahwa herbisida parakuat diklorida dengan dosis $414 \mathrm{~g} / \mathrm{ha}-966 \mathrm{~g} / \mathrm{ha}$ mampu menekan bobot kering gulma total pada 2, 4, dan 8 MSA dan sama efektifnya dengan perlakuan penyiangan mekanis (Tabel 2). Hal tersebut dapat dilihat dari nilai bobot kering gulma total perlakuan herbisida parakuat diklorida untuk semua taraf dosis dan penyiangan mekanis lebih rendah dibandingkan dengan kontrol. Dengan demikian aplikasi herbisida parakuat diklorida untuk mengendalikan gulma umum pada tanaman ubi kayu menunjukkan kinerja yang baik karena mampu menekan pertumbuhan gulma. Hal ini dapat terjadi karena herbisida parakuat diklorida merupakan herbisida kontak dan nonselektif. Herbisida ini mampu mematikan semua jenis gulma pada bagian yang terkena larutan herbisida secara langsung, karena dosis dan waktu aplikasi yang digunakan sudah tepat sehingga herbisida tersebut efektif dalam mengendalikan gulma (Hermania, dkk., 2010).

Tabel 1. Pengaruh herbisida terhadap penutupan gulma total (\%).

\begin{tabular}{clllll}
\hline \multirow{2}{*}{ No } & \multirow{2}{*}{ Perlakuan } & Dosis $(\mathrm{g} / \mathrm{ha})$ & \multicolumn{3}{c}{ Penutupan Gulma Total (\%) } \\
\cline { 4 - 6 } & & 414 & $2 \mathrm{MSA}$ & $4 \mathrm{MSA}$ & $8 \mathrm{MSA}$ \\
\hline \multirow{2}{*}{1} & Parakuat Diklorida & 552 & $48,50 \mathrm{~b}$ & $64,88 \mathrm{bc}$ & $82,38 \mathrm{~b}$ \\
2 & Parakuat Diklorida & 690 & $27,50 \mathrm{c}$ & $49,75 \mathrm{bc}$ & $60,53 \mathrm{c}$ \\
3 & Parakuat Diklorida & 828 & $26,00 \mathrm{c}$ & $54,00 \mathrm{bc}$ & $50,00 \mathrm{~cd}$ \\
4 & Parakuat Diklorida & 966 & $30,13 \mathrm{bc}$ & $45,88 \mathrm{bc}$ & $41,25 \mathrm{~d}$ \\
5 & Parakuat Diklorida & - & $41,50 \mathrm{bc}$ & $42,00 \mathrm{c}$ & $50,00 \mathrm{~cd}$ \\
6 & Penyiangan mekanis & - & $98,38 \mathrm{a}$ & $99,75 \mathrm{a}$ & $100,0 \mathrm{a}$ \\
7 & Kontrol & & 24,47 & 24,73 & 15,4 \\
\hline & BNT 0,05 & & &
\end{tabular}

Keterangan: Nilai tengah pada setiap kolom yang diikuti oleh huruf yang sama tidak berbeda nyata menurut uji BNT pada taraf $5 \%$.

Tabel 2. Pengaruh herbisida terhadap bobot kering gulma total $\left(\mathrm{g} / 0,5 \mathrm{~m}^{2}\right)$.

\begin{tabular}{llcrrr}
\hline & \multirow{2}{*}{ No } & \multirow{2}{*}{$\begin{array}{c}\text { Dosis } \\
(\mathrm{g} / \mathrm{ha})\end{array}$} & $2 \mathrm{MSA}$ & $4 \mathrm{MSA}$ & $8 \mathrm{MSA}$ \\
\cline { 3 - 6 } & & 414 & $15,69 \mathrm{~b}$ & $20,85 \mathrm{~cd}$ & $30,99 \mathrm{~b}$ \\
& & 552 & $14,56 \mathrm{~b}$ & $33,81 \mathrm{~b}$ & $29,74 \mathrm{~b}$ \\
2 & Parakuat Diklorida & Parakuat Diklorida & $12,89 \mathrm{~b}$ & $31,02 \mathrm{bc}$ & $24,93 \mathrm{~b}$ \\
3 & Parakuat Diklorida & 828 & $11,22 \mathrm{~b}$ & $18,85 \mathrm{~cd}$ & $31,75 \mathrm{~b}$ \\
4 & Parakuat Diklorida & 966 & $11,42 \mathrm{~b}$ & $34,19 \mathrm{~b}$ & $43,66 \mathrm{~b}$ \\
5 & Parakuat Diklorida & - & $4,45 \mathrm{~b}$ & $9,77 \mathrm{~d}$ & $26,37 \mathrm{~b}$ \\
6 & Penyiangan mekanis & - & $78,35 \mathrm{a}$ & $58,33 \mathrm{a}$ & $70,38 \mathrm{a}$ \\
7 & Kontrol & & 11,51 & 12,55 & 21,90
\end{tabular}

Keterangan: Nilai tengah pada setiap kolom yang diikuti oleh huruf yang sama tidak berbeda nyata menurut uji BNT pada taraf $5 \%$. 
Pada bobot kering gulma dominan, gulma dominan diperoleh berdasarkan gulma yang terdapat pada petak kontrol pasca aplikasi herbisida parakuat diklorida saat 2, 4, dan 8 MSA. Gulma dominan ditentukan berdasarkan nilai SDR masing-masing spesies gulma pada saat aplikasi. Gulma-gulma yang ditemukan pasca aplikasi herbisida parakuat diklorida adalah I. triloba (Kangkung Bulu), R. brasiliensis (Goletrak Beuti), D. ciliaris (Ceker Ayam), dan E. colonum (Rumput Bebek). Hal ini serupa dengan penelitian Riry (2006), lahan yang diaplikasikan dengan herbisida pasca tumbuh jenis parakuat diklorida akan didominasi oleh jenis daun lebar dan rumput-rumputan seperti Altenanthera sessilis, I. triloba, R. brasiliensis, C. dactylon, dan E. colonum. C. rutidosperma pasca aplikasi herbisida parakuat diklorida tidak muncul sebagai gulma dominan. Pada 2 MSA C. rutidosperma muncul di petak kontrol, namun pada 4 dan 8 MSA tidak muncul pada petak kontrol. Hal ini dapat terjadi karena diduga bahwa telah terjadi interspesific competition pada lahan akibat pengaruh gulma yang lain. Gulma-gulma yang dahulu menjadi gulma dominan dapat menjadi gulma yang tidak dominan berganti dengan gulma yang lain maupun tidak muncul pada petak pengamatan. C. rutidosperma dapat diduga mati karena siklus hidup yang pendek disebabkan gulma ini merupakan salah satu gulma semusim (berumur \pm 3 bulan).

Pada bobot kering gulma I. triloba pengamatan 2, 4, dan $8 \mathrm{MSA}$, herbisida parakuat diklorida mampu menekan dan mengendalikan pertumbuhan gulma $I$. triloba dan sama efektifnya dengan perlakuan penyiangan mekanis, kecuali pada taraf dosis $690 \mathrm{~g} / \mathrm{ha}$ saat $4 \mathrm{MSA}$ dan $966 \mathrm{~g} / \mathrm{ha}$ saat $8 \mathrm{MSA}$. Pengaruh herbisida parakuat diklorida terhadap bobot kering gulma I. triloba dipaparkan pada Tabel 3.

Pada bobot kering gulma $R$. brasiliensis pengamatan 2, 4, dan 8 MSA, bobot kering gulma $R$. brasiliensis pada semua taraf dosis herbisida parakuat diklorida dan penyiangan mekanis terkendali (Tabel 4). Hal ini diduga karena herbisida parakuat diklorida bersifat kontak dan mematikan bagian gulma yang terkena langsung herbisida dengan menghasilkan radikal hidrogen peroksida $\left(\mathrm{H}_{2} \mathrm{O}_{2}\right)$ yang memecah membran sel sehingga parakuat diklorida mampu meracuni gulma R. brasiliensis. Moenandir (1993) menyatakan, beberapa hal yang berhubungan dengan keefektifan dan penggunaan herbisida adalah kuantitas absorbsi dan kualitas translokasi yang dipengaruhi oleh jenis gulma, stadia pertumbuhan, genetik, fisiologi, anatomi dan morfologi daun.

Pada pengamatan 4 MSA herbisida parakuat diklorida dan penyiangan mekanis mampu menekan pertumbuhan gulma $R$. brasiliensis kecuali pada dosis $690 \mathrm{~g} / \mathrm{ha}$. Tidak terkendalinya gulma $R$. brasiliensis pada taraf dosis tersebut diduga disebabkan karena gulma tersebut tumbuh kembali (regrowth). Pengaruh perlakuan herbisida parakuat diklorida terhadap bobot kering gulma $R$. brasiliensis ditunjukkan pada Tabel 4. Pada pengamatan $8 \mathrm{MSA}$ herbisida parakuat diklorida $414 \mathrm{~g} /$ ha dan $828 \mathrm{~g} /$ ha tidak mampu menekan gulma $R$. brasiliensis.

Pada bobot kering gulma $D$. ciliaris pengamatan 2 dan 4 MSA, herbisida parakuat diklorida yang diuji termasuk penyiangan mekanis mampu menekan dan mengendalikan pertumbuhan gulma $D$. ciliaris (Tabel 5). Hal ini diduga bahwa seluruh bagian gulma teracuni

Tabel 3. Pengaruh herbisida terhadap bobot kering gulma I. triloba $\left(\mathrm{g} / 0,5 \mathrm{~m}^{2}\right)$.

\begin{tabular}{llcccc}
\hline & \multirow{2}{*}{ No } & \multirow{2}{*}{$\begin{array}{c}\text { Dosis } \\
\mathrm{n} / \mathrm{ha}\end{array}$} & & \multicolumn{4}{c}{ Bobot Kering $\left(\mathrm{g} / 0,5 \mathrm{~m}^{2}\right)$} \\
\cline { 4 - 6 } & & 414 & $1,02 \mathrm{~b}$ & $0,37 \mathrm{bc}$ & $0,00 \mathrm{c}$ \\
\hline 1 & Parakuat Diklorida & 552 & $1,27 \mathrm{~b}$ & $0,49 \mathrm{bc}$ & $0,17 \mathrm{c}$ \\
2 & Parakuat Diklorida & 690 & $0,61 \mathrm{~b}$ & $0,79 \mathrm{ab}$ & $0,40 \mathrm{c}$ \\
3 & Parakuat Diklorida & 828 & $0,26 \mathrm{~b}$ & $0,32 \mathrm{bc}$ & $0,48 \mathrm{bc}$ \\
4 & Parakuat Diklorida & 966 & $0,38 \mathrm{~b}$ & $0,48 \mathrm{bc}$ & $2,31 \mathrm{ab}$ \\
5 & Parakuat Diklorida & - & $0,07 \mathrm{~b}$ & $0,00 \mathrm{c}$ & $0,00 \mathrm{c}$ \\
6 & Penyiangan mekanis & - & $4,19 \mathrm{a}$ & $1,32 \mathrm{a}$ & $4,07 \mathrm{a}$ \\
7 & Kontrol & & 2,39 & 0,63 & 1,90 \\
\hline & BNT 0,05 & &
\end{tabular}

Keterangan: Nilai tengah pada setiap kolom yang diikuti oleh huruf yang sama tidak berbeda nyata menurut uji BNT pada taraf $5 \%$. 
Tabel 4. Pengaruh herbisida terhadap bobot kering gulma $R$. brasiliensis $\left(\mathrm{g} / 0,5 \mathrm{~m}^{2}\right)$.

\begin{tabular}{llcrrr}
\hline & & \multirow{2}{*}{$\begin{array}{c}\text { Dosis } \\
\text { No }\end{array}$} & & \multicolumn{3}{c}{ Bobot Kering $\left(\mathrm{g} / 0,5 \mathrm{~m}^{2}\right)$} \\
\cline { 3 - 6 } & & & $2 \mathrm{gSA}$ & $4 \mathrm{MSA}$ & $8 \mathrm{MSA}$ \\
\hline 1 & Parakuat Diklorida & 414 & $5,63 \mathrm{~b}$ & $6,72 \mathrm{bc}$ & $11,07 \mathrm{ab}$ \\
2 & Parakuat Diklorida & 552 & $3,31 \mathrm{~b}$ & $17,86 \mathrm{~b}$ & $3,92 \mathrm{~b}$ \\
3 & Parakuat Diklorida & 690 & $3,86 \mathrm{~b}$ & $21,17 \mathrm{ab}$ & $1,72 \mathrm{~b}$ \\
4 & Parakuat Diklorida & 828 & $3,20 \mathrm{~b}$ & $5,65 \mathrm{bc}$ & $7,00 \mathrm{ab}$ \\
5 & Parakuat Diklorida & 966 & $3,77 \mathrm{~b}$ & $11,82 \mathrm{bc}$ & $5,75 \mathrm{~b}$ \\
6 & Penyiangan mekanis & - & $1,07 \mathrm{~b}$ & $1,05 \mathrm{c}$ & $5,79 \mathrm{~b}$ \\
7 & Kontrol & - & $30,86 \mathrm{a}$ & $34,07 \mathrm{a}$ & $22,31 \mathrm{a}$ \\
\hline & BNT 0,05 & & 7,22 & 15,56 & 15,4 \\
\hline
\end{tabular}

Keterangan: Nilai tengah pada setiap kolom yang diikuti oleh huruf yang sama tidak berbeda nyata menurut uji BNT pada taraf $5 \%$.

Tabel 5. Pengaruh herbisida terhadap bobot kering gulma D. ciliaris $\left(\mathrm{g} / 0,5 \mathrm{~m}^{2}\right)$.

\begin{tabular}{|c|c|c|c|c|c|}
\hline \multirow{2}{*}{ No } & \multirow{2}{*}{ Perlakuan } & \multirow{2}{*}{$\begin{array}{l}\text { Dosis } \\
\text { (g/ha) }\end{array}$} & \multicolumn{3}{|c|}{ Bobot Kering $\left(\mathrm{g} / 0,5 \mathrm{~m}^{2}\right)$} \\
\hline & & & $2 \mathrm{MSA}$ & $4 \mathrm{MSA}$ & $8 \mathrm{MSA}$ \\
\hline 1 & Parakuat Diklorida & 414 & $0,86 \mathrm{~b}$ & $2,69 \mathrm{~b}$ & $0,02 \mathrm{~d}$ \\
\hline 2 & Parakuat Diklorida & 552 & $0,94 \mathrm{~b}$ & $2,60 \mathrm{~b}$ & $0,21 \mathrm{~d}$ \\
\hline 3 & Parakuat Diklorida & 690 & $1,41 \mathrm{~b}$ & $0,96 \mathrm{~b}$ & $3,63 \mathrm{bc}$ \\
\hline 4 & Parakuat Diklorida & 828 & $1,14 \mathrm{~b}$ & $1,67 \mathrm{~b}$ & $2,16 \mathrm{~cd}$ \\
\hline 5 & Parakuat Diklorida & 966 & $0,74 \mathrm{~b}$ & $0,73 \mathrm{~b}$ & 7,40 a \\
\hline 6 & Penyiangan mekanis & - & $0,84 \mathrm{~b}$ & $1,19 \mathrm{~b}$ & $2,12 \mathrm{~cd}$ \\
\hline 7 & Kontrol & - & 17,18 a & 6,02 a & $6,46 \mathrm{ab}$ \\
\hline & $B N T 0,05$ & & 2,92 & 3,30 & 2,90 \\
\hline
\end{tabular}

Keterangan: Nilai tengah pada setiap kolom yang diikuti oleh huruf yang sama tidak berbeda nyata menurut uji BNT pada taraf $5 \%$.

oleh herbisida parakuat diklorida karena waktu pengaplikasian dan dosis yang digunakan sudah tepat sehingga herbisida tersebut efektif dalam mengendalikan gulma. Pada pengamatan 8 MSA semua perlakuan herbisida yang diuji termasuk penyiangan mekanis mampu menekan dan mengendalikan pertumbuhan gulma $D$. ciliaris kecuali pada taraf dosis $966 \mathrm{~g} / \mathrm{ha}$ karena telah mengalami pemulihan kembali (regrowth).

Pada bobot kering gulma E. colonum, pengaruh perlakuan herbisida parakuat diklorida terhadap bobot kering gulma E. colonum dapat dilihat pada Tabel 6 . Pada pengamatan bobot kering gulma $E$. colonum pada 2, 4, dan 8 MSA, herbisida parakuat diklorida tidak mampu menekan pertumbuhan gulma $E$. colonum begitu pula dengan penyiangan mekanis kecuali pada taraf dosis $552 \mathrm{~g} /$ ha dan $966 \mathrm{~g} /$ ha saat $4 \mathrm{MSA}$. Hal ini mungkin disebabkan karena herbisida parakuat diklorida bersifat kontak sehingga tidak ditranslokasikan ke seluruh jaringan gulma E. colonum (Wentrisno, dkk., 1999). Selain itu morfologi daun $E$. colonum yang tegak dan sempit hanya dapat menyerap sedikit butiran herbisida yang diaplikasikan. Gulma golongan rumput memiliki alat perkembangbiakan ganda berupa biji dan rhizom yang berada di dalam tanah, sehingga akan tetap hidup walaupun bagian daun terkena herbisida karena akar lebih toleran (Moenandir, 1990). Hal ini juga dapat disebabkan karena pada gulma rumput terdapat mekanisme dormansi biji dengan kondisi lahan yang terbuka maka biji gulma yang sebelumnya dorman dapat tumbuh dan berkecambah.

Menurut Moenandir (1993), apabila metode pengendalian yang dipilih dengan cara mekanis atau 
dengan menggunakan herbisida pasca tumbuh, maka biji gulma yang terkendali adalah yang tumbuh menjadi kecambah, sedangkan biji yang berada di dalam permukaan tanah akan berkecambah dan membentuk tumbuhan baru. Tidak terkendalinya gulma $E$. colonum diduga tumbuh kembalinya gulma tersebut walaupun telah mengalami gejala keracunan dan banyaknya populasi gulma $E$. colonum dari biji maupun rhizom (Sabur, 2003) sedangkan target aksi herbisida parakuat bersifat kontak pada bagian yang terkena sewaktu penyemprotan herbisida (Wentrisno, dkk., 1999).

Pengaruh aplikasi herbisida parakuat diklorida terhadap tinggi tanaman ubi kayu dapat dilihat pada Tabel 7. Pada pengamatan 2, 4 dan 8 MSA, semua taraf dosis herbisida parakuat diklorida tidak menekan tinggi tanaman ubi kayu kecuali pada taraf dosis $690 \mathrm{~g} / \mathrm{ha}$. Hal ini diduga bahwa aplikasi herbisida parakuat diklorida pada lahan tidak menekan pertumbuhan ubi kayu karena mampu mengendalikan gulma sehingga memberikan kesempatan pada tanaman untuk tumbuh lebih baik. Pada pengamatan 4 MSA semua aplikasi herbisida parakuat diklorida dan penyiangan mekanis pada lahan ubi kayu tidak menekan tinggi tanaman ubi kayu. Sedangkan pada pengamatan 8 MSA, hanya perlakuan penyiangan mekanis yang menekan tinggi tanaman ubi kayu. Hal ini disebabkan pada petak penyiangan mekanis gulma dikendalikan secara menyeluruh dengan menghilangkan gulma pada petak pengamatan. Sedangkan tinggi

Tabel 6. Pengaruh herbisida terhadap bobot kering gulma E. colonum $\left(\mathrm{g} / 0,5 \mathrm{~m}^{2}\right)$.

\begin{tabular}{|c|c|c|c|c|c|}
\hline \multirow{2}{*}{ No } & \multirow{2}{*}{ Perlakuan } & \multirow{2}{*}{$\begin{array}{l}\text { Dosis } \\
\text { (g/ha) }\end{array}$} & \multicolumn{3}{|c|}{ Bobot Kering $\left(\mathrm{g} / 0,5 \mathrm{~m}^{2}\right)$} \\
\hline & & & $2 \mathrm{MSA}$ & $4 \mathrm{MSA}$ & $8 \mathrm{MSA}$ \\
\hline 1 & Parakuat Diklorida & 414 & $1,27 \mathrm{ab}$ & $3,07 \mathrm{~b}$ & $1,47 \mathrm{ab}$ \\
\hline 2 & Parakuat Diklorida & 552 & $3,08 \mathrm{ab}$ & $0,00 \mathrm{c}$ & $2,67 \mathrm{a}$ \\
\hline 3 & Parakuat Diklorida & 690 & $2,78 \mathrm{ab}$ & $2,59 \mathrm{~b}$ & 2,52 a \\
\hline 4 & Parakuat Diklorida & 828 & $1,47 \mathrm{ab}$ & $2,63 \mathrm{~b}$ & $0,35 \mathrm{~b}$ \\
\hline 5 & Parakuat Diklorida & 966 & $1,38 \mathrm{ab}$ & $10,12 \mathrm{a}$ & $2,26 \mathrm{a}$ \\
\hline 6 & Penyiangan mekanis & - & $0,55 \mathrm{~b}$ & $0,00 \mathrm{c}$ & $0,92 \mathrm{~b}$ \\
\hline \multirow[t]{2}{*}{7} & Kontrol & - & 4,35 a & $3,91 \mathrm{~b}$ & $1,41 \mathrm{ab}$ \\
\hline & BNT 0,05 & & 3,19 & 1,95 & 1,33 \\
\hline
\end{tabular}

Keterangan: Nilai tengah pada setiap kolom yang diikuti oleh huruf yang sama tidak berbeda nyata menurut uji BNT pada taraf $5 \%$.

Tabel 7. Pengaruh herbisida terhadap tinggi tanaman $(\mathrm{cm})$.

\begin{tabular}{|c|c|c|c|c|c|c|c|c|}
\hline \multirow{3}{*}{ No } & \multirow{3}{*}{ Perlakuan } & \multirow{3}{*}{$\begin{array}{l}\text { Dosis } \\
\text { (g/ha) }\end{array}$} & \multicolumn{6}{|c|}{ Tinggi Tanaman $(\mathrm{cm})$} \\
\hline & & & \multicolumn{2}{|c|}{$2 \mathrm{MSA}$} & \multicolumn{2}{|c|}{$4 \mathrm{MSA}$} & \multicolumn{2}{|c|}{$8 \mathrm{MSA}$} \\
\hline & & & Asli & $\begin{array}{c}\text { Trans } \\
\sqrt{(x+0,5)} \\
\end{array}$ & Asli & $\begin{array}{c}\text { Trans } \\
\sqrt{(x+0,5)} \\
\end{array}$ & Asli & $\begin{array}{c}\text { Trans } \\
\sqrt{(x+0,5)} \\
\end{array}$ \\
\hline 1 & Parakuat Diklorida & 414 & 49,28 & $7,05 \mathrm{ab}$ & 69,75 & $8,35 \mathrm{a}$ & 93,57 & $9,65 \mathrm{ab}$ \\
\hline 2 & Parakuat Diklorida & 552 & 49,25 & $7,05 \mathrm{ab}$ & 78,78 & 8,88 a & 105,75 & $10,24 \mathrm{ab}$ \\
\hline 3 & Parakuat Diklorida & 690 & 52,63 & $7,28 \mathrm{a}$ & 72,56 & $8,54 \mathrm{a}$ & 105,56 & $10,27 \mathrm{ab}$ \\
\hline 4 & Parakuat Diklorida & 828 & 50,63 & $7,13 a b$ & 81,00 & 8,95 a & 103,44 & $10,10 a b$ \\
\hline 5 & Parakuat Diklorida & 966 & 46,74 & $6,86 a b$ & 71,44 & 8,46 a & 102,69 & $10,10 a b$ \\
\hline 6 & Penyiangan mekanis & - & 46,42 & $6,84 \mathrm{~b}$ & 69,09 & 8,31 a & 114,35 & $10,71 \mathrm{a}$ \\
\hline \multirow[t]{2}{*}{7} & Kontrol & - & 48,19 & $6,98 \mathrm{ab}$ & 63,56 & 7,99 a & 83,19 & $9,12 \mathrm{~b}$ \\
\hline & BNT 0,05 & & 6,05 & & 18,92 & & 30,98 & \\
\hline
\end{tabular}

Keterangan: Nilai tengah pada setiap kolom yang diikuti oleh huruf yang sama tidak berbeda nyata menurut uji BNT pada taraf $5 \%$. 
tanaman pada kontrol lebih rendah dibandingkan dari semua perlakuan, baik perlakuan herbisida maupun penyiangan mekanis. Hal ini dipengaruhi oleh gulma pada petak pengamatan yang tidak dikendalikan sehingga menekan tinggi tanaman ubi kayu. Sehingga hebisida dengan bahan aktif parakuat diklorida dapat dijadikan salah satu alternatif untuk mengendalikan gulma pada tanaman ubi kayu hingga 8 MSA bila dilihat dari penekanan bobot kering gulma total Pengguna dianjurkan memakai herbisida parakuat diklorida pada taraf dosis terendah terutama untuk mengendalikan gulma golongan daun lebar, karena pada dosis yang rendah (414 g/ha).

\section{KESIMPULAN}

Berdasarkan hasil penelitian dapat disimpulkan bahwa herbisida parakuat diklorida dengan dosis $414 \mathrm{~g} /$ ha"966 g/ha mampu menekan pertumbuhan gulma total ubi kayu sampai 8 MSA dan mampu mengendalikan gulma golongan daun lebar Ipomoea triloba, dan Richardia brasiliensis hingga 8 MSA serta gulma golongan rumput Digitaria ciliaris hingga 4 MSA namun demikian parakuat diklorida dosis $414 \mathrm{~g} / \mathrm{ha}$ "966 g/ha tidak dapat mengendalikan gulma golongan rumput Echinochloa colonum dari 2 MSA hingga 8 MSA.

\section{DAFTAR PUSTAKA}

Adnan, H., dan Manfarizah. 2012. Aplikasi Beberapa Dosis Herbisida Glifosat dan Parakuat Diklorida pada Sistem Tanpa Olah Tanah (TOT) serta Pengaruhnya terhadap Sifat Kimia Tanah, Karakteristik Gulma dan Hasil Kedelai. $J$. Agrista 16 (3):135-145.

Anwar. 2002. Residu Herbisida Paraquat + Diuron pada Baby Corn. J. Akta Agro 5 (1): 35-40.

Badan Pusat Statistik. 2013. Statistik Indonesia 2011 (Produksi Umbi-umbian di Indonesia). http:// www.google.com/produksiubikayutahun2011/ 2013. Diakses pada tanggal : 14 November 2014.

Hermania, W., S. M. F. Ledoh, dan P. D. Rozari. 2010. Studi Kinetika Degradasi Paraquat (1,1Dimetil-4,4-Bipiridilium) dalamLingkungan Tanah Pertanian Kabupaten Kupang. J. Media Exacta $10(2): 1-10$.

Moenandir, J. 1993. Ilmu Gulma dalam Sistem Pertanian. PT. Raja Grafindo Persada. Jakarta. $181 \mathrm{hlm}$.
Muktamar, Z. 2004. Adsorpsi dan Desorpsi Herbisida Paraquat oleh Bahan Organik Tanah. J. Akta Agrosia 1 (1): 1-8.

Riry, J. 2006. Daya Saing Tanaman Kedelai Hasil Desikasi Herbisida Parakuat dan Glifosat terhadap Cekaman Gulma. J. Agrista 10 (1): 21-26.

Sabur, A. M. 2003. Pengendalian Gulma dengan Serasah Pangkasan dan Rotasi di Perkebunan Teh. Dalam Herbisida Olah Tanah Konservasi Prosiding Himpunan Ilmu Gulma Indonesia tanggal 15-17 Juli 2003. Seameo Biotrop. Bogor. Hlm. 75-85.

Sarbino dan E. Syahputra. 2012. Keefektifan Parakuat Diklorida sebagai Herbisida Persiapan Tanam Padi Tanpa Olah Tanah di Lahan Pasang Surut. J. Perkebunan dan Lahan Tropika 2 (1): 1522.

Sembodo, D. R. J. 2010. Gulma dan Pengelolaannya. Graha Ilmu. Yogyakarta. 166 hlm.

Sriyani, N., dan A. K. Salam. 2008. Penggunaan metode Bioassay untuk Mendeteksi Pergerakan Herbisida Pasca Tumbuh Paraquat dan 2,4-D dalam Tanah. J. Tanah Tropika 13 (3): 199208.

Sukman, Y, dan Yakup. 2002. Gulma dan Teknik Pengendaliannya. PT. Raja Grafindo Persada. Jakarta. $131 \mathrm{hlm}$.

Tjitrosoedirdjo, S., I. H. Utomo, dan J. Wiroatmodjo. 1984. Pengelolaan Gulma di Perkebunan. PT. Gramedia. Jakarta. 209 hlm.

Wentrisno, Z. Lamid, Z. Hamzah, dan D. A. Mannan. 1999. Efikasi Herbisida Parakuat Diklorida dan Sulfosat terhadap Gulma Persiapan Lahan Tanam Tanpa Olah Tanah Jagung pada Lahan Gambut. Dalam Pengembangan Pengelolaan Gulma secara Efisien Berwawasan Lingkungan Menuju Pertanian Berkelanjutan. Prosiding II Himpunan Ilmu Gulma Indonesia. tanggal 20-22 Juli 1999. Medan. Hlm. 394-410.

Yuni, E. S., dan H. Suyani. 2008. Degradasi Senyawa Paraquat dalam Pestisida Gramoxone Secara Fotolisis dengan Penambahan $\mathrm{TiO}_{2}$-Anatase. J. Ris. Kim 2 (1): 1-8. 